\title{
Distal biceps tendon rupture
}

Olga D. Savvidou • Panayiotis J. Papagelopoulos •

Andreas F. Mavrogenis • Antonios A. Partsinevelos •

Efthymios J. Karadimas • Demetrios S. Korres

Published online: 19 September 2006

(C) Springer-Verlag 2006

Erratum to: Eur J Orthop Surg Traumatol 14:155-160 DOI 10.1007/s00590-004-0153-2

Owing to an unfortunate error, the first name of Dr. Karadimas was mistakenly given as Evangelos. It should be Efthymios.

The online version of the original article can be found at http://dx.doi.org//10.1007/s00590-004-0153-2.

O. D. Savvidou · P. J. Papagelopoulos · A. F. Mavrogenis ·

A. A. Partsinevelos · E. J. Karadimas - D. S. Korres

First Department of Orthopedics,

Athens University Medical School,

Athens, Greece

P. J. Papagelopoulos $(\varangle)$

4 Christovassili Street,

15451 Neo Psychicon,

Athens, Greece

e-mail: pjp@hol.gr 